\title{
Reaction norm in response to temperature may change to adapt rapid brood development to boreal and subarctic climates in Myrmica ants (Hymenoptera: Formicidae)
}

\author{
VLADILEN E. KIPYATKOV ${ }^{1}$ and ELENA B. LOPATINA ${ }^{2}$ \\ ${ }^{1}$ Department of Entomology, Faculty of Biology and Soil Sciences, St. Petersburg State University, 7/9 Universitetskaya emb., \\ St. Petersburg, 199034, Russia; e-mail: vk@vk1280.spb.edu \\ ${ }^{2}$ Laboratory of Entomology, Biological Research Institute of St. Petersburg University, 2 Oranienbaumskoye shosse, Petergof, St. \\ Petersburg, 198904, Russia
}

Key words. Formicidae, ants, Myrmica rubra, Myrmica ruginodis, Myrmica scabrinodis, latitude, reaction norm, temperature, rapid brood rearing, development rate, thermal threshold, thermal constants

\begin{abstract}
Colonies of M. rubra, M. ruginodis and M. scabrinodis were collected in four geographic regions: Kiev, Ukraine (50.5 ${ }^{\circ} \mathrm{N}$, $30.5^{\circ} \mathrm{E}$ - first two species), Vladimir, Russia $\left(56.2^{\circ} \mathrm{N}, 40.4^{\circ} \mathrm{E}-\right.$ only last species), St. Petersburg, Russia $\left(59.3^{\circ} \mathrm{N}, 30.3^{\circ} \mathrm{E}-\right.$ all three species) and Chupa, Murmansk prov., Russia $\left(66.3^{\circ} \mathrm{N}, 33.7^{\circ} \mathrm{E}\right.$ - last two species). After artificial overwintering experimental cultures consisting of 150 workers and one queen were established and kept at 16,18,20,22, 24 and $26^{\circ} \mathrm{C}$ under long (22 h) day lengths. The workers reared eggs laid by queens into rapid (non-diapause) brood pupae and diapause larvae, which were removed and counted. The results showed the distinct latitudinal variation in the temperature effects on rapid brood rearing and in the thermal requirements for development. First, the period during which new rapid brood pupae appeared was found to be longer and the total number of pupae produced to be greater in ants from more southern populations. The number of diapause larvae reared by ant cultures was also usually greater, in ants from southern sites. Second, low temperatures reduced the period of rapid brood production and the number of pupae reared to a greater degree in ants from northern populations. It means that northern Myrmica colonies rear rapid brood under lower temperatures evidently worse in comparison with ants from southern regions. Third, eggs and larvae from more northern sites appeared to develop faster than southern brood at temperatures above $16-18^{\circ} \mathrm{C}$. This was because brood development in northern populations was more temperature dependent, i.e. characterised by higher slopes of regression lines of development rate on temperature. The sum of effective temperatures decreased with the advance to North. The higher slopes were always associated with higher thermal thresholds for development. We conclude that the reaction norm of Myrmica colonies, in response to temperature, changes according to the local climate in such a way that brood rearing, growth and development of individuals become more temperature dependent in more severe environments with colder and shorter summers. This lead to the increase of the physiological and developmental responses at higher temperatures at the expense of a decrease within lower temperature range. In fact Myrmica colonies from northern populations need on average higher temperatures in their nests for successful production of new adults as compared to southern ants.
\end{abstract}

\section{INTRODUCTION}

Ants, despite being generally thermophilic, have successfully penetrated as far to the North as the sub-arctic forest-tundra zone (Holgersen, 1942; Kusnezov, 1957). Although the importance of ants in boreal ecosystems is well acknowledged (e.g. Brian, 1983; Nielsen, 1987) surprisingly few studies have been devoted to the adaptations of these insects to the harsh climatic conditions of the North (Heinze \& Hölldobler, 1994). In particular, almost nothing is known about the thermal requirements of development in boreal and sub-arctic species and populations of ants.

Our preliminary studies (Lopatina et al., 1999) suggested that southern and northern populations of Myrmica ants differed in the physiological response of colonies to temperature. We expected that such changes of the reaction norm to temperature in response to differences in local climate might be detected in the best way in experiments with ant colonies collected in several regions along latitudinal gradient from South to North. To make such experiments was the main goal of our study.
It is generally supposed that arctic and subarctic poikilotherms should be better adapted to grow and develop at low temperatures compared to their temperate counterparts. Indeed, the threshold temperatures for respiration, activity, feeding, development and emergence have long been shown to be very low in many arthropod species of northern origin (Downes, 1965; Danks, 1981). One more goal of our study was, therefore, to examine if this could hold also for Myrmica ants which are rather common and numerous in boreal habitats (Holgersen, 1942).

Ants of the genus Myrmica employ the strategy of prolonged brood-rearing which means that their colonies overwinter with larvae in diapause (Kipyatkov, 2001). In spring queens begin to lay eggs: however, only a part of the larvae which develop from these eggs, pupate during the same summer. These are the so-called rapid or summer brood (Brian, 1951, 1957). A large proportion of the larvae continue to grow slowly in autumn, overwinter in diapause and pupate during the next summer; these are usually called slow or winter brood (Brian, 1951, 1957). In late summer queens enter diapause and stop laying. 
Larvae can only diapause in the third (final) instar, any eggs and young larvae that fail to reach the final instar before winter die so that all overwintering brood consists of third instar larvae (Brian, 1951; Elmes \& Thomas, 1987; Elmes, 1991).

The duration of Myrmica colony's annual cycle of brood-rearing is controlled both by an endogenous timer and by external ecological factors - temperature and photoperiod. The environmental factors adjust the date of diapause onset in queens and larvae to the climatic characteristics of a given year. In late summer the lower temperature and short days induce the diapause thus curtailing the period of development (Kipyatkov, 1974, $1977,1993,2001)$. The winter diapause is, however, obligatory at a colony level and possible period of nondiapause development is strongly limited by endogenous factors in most temperate and especially boreal ants (including the genus Myrmica): In laboratory experiments, even at long days and optimal temperatures, diapause ensues and brood-rearing ceases sooner or later as a result of an internal timing effect (Kipyatkov, 1993, 1995, 2001). Myrmica populations adapt to distinct local climates by changing the period of rapid brood rearing and the amount of pupae produced which leads to a definite latitudinal variation of these parameters. This is controlled mainly by innate endogenous mechanisms: The length of Myrmica colony's intrinsic cycle of broodrearing was found to be shorter in more northerly populations of the same species even if colonies were reared in common garden conditions (Kipyatkov \& Lopatina, 1997).

\section{MATERIALS AND METHODS}

Stock colonies of Myrmica rubra L., M. ruginodis Nylander and $M$. scabrinodis Nylander were collected at the end of summer in four geographic regions: Kiev, Ukraine $\left(50.5^{\circ} \mathrm{N}\right.$, $30.5^{\circ} \mathrm{E}$ - first two species), Vladimir, Russia (Yurievets, $56.2^{\circ} \mathrm{N}, 40.4^{\circ} \mathrm{E}$ - only last species), St. Petersburg, Russia (Vyritsa, $59.3^{\circ} \mathrm{N}, 30.3^{\circ} \mathrm{E}$ - all three species) and Chupa, Murmansk prov., Russia $\left(66.3^{\circ} \mathrm{N}, 33.7^{\circ} \mathrm{E}\right.$ - last two species). All sites were at low altitudes. In Kiev and St. Petersburg regions $M$. rubra and $M$. ruginodis lived together in the same habitat: near Kiev in deciduous oak forest nesting mainly in rotten wood and near St. Petersburg in coniferous pine woodland mostly in moss hillocks. M. scabrinodis lived mostly in soil mounds on grass meadows and clearings in deciduous woodland near Vladimir and in moss hillocks in the bogs near St. Petersburg. Near Chupa both $M$. ruginodis and $M$. scabrinodis occurred mainly in the bogs nesting in moss hillocks.

Before the experiments stock colonies were subjected to artificial overwintering in a refrigerator at $3-5^{\circ} \mathrm{C}$ for 4 months Thus, they were physiologically in early spring state, just at the beginning of annual cycle of brood-rearing (Brian, 1955; Kipyatkov, 1993, 2001). Following the overwintering colonies were kept at $10^{\circ} \mathrm{C}$ and at $15^{\circ} \mathrm{C}$ (for a week at each temperature), and after that the experimental cultures consisted of 150 workers and one queen were established (all overwintered larvae were removed from colonies). From 11 to 18 stock colonies of each species from each site were used, which were both monogynous and polygynous. Each monogynous colony gave rise to one experimental culture. Polygynous colonies were used to establish from 2 to 8 experimental cultures each. In the latter case cultures originating from the same stock colony were evenly distributed among experimental regimes.

Ant cultures were maintained in plastic laboratory nests with approximately 100\% humidity and food (cockroaches Nauphoeta cinerea cut into pieces and 15\% sucrose solution) added twice a week in photo thermostatic chambers (photothermostats). Six constant temperatures $\left(16 \pm 0.2^{\circ} \mathrm{C}, 18 \pm 0.2^{\circ} \mathrm{C}, 20\right.$ $\pm 0.2^{\circ} \mathrm{C}, 22 \pm 0.2^{\circ} \mathrm{C}, 24 \pm 0.2^{\circ} \mathrm{C}$ and $26 \pm 0.2^{\circ} \mathrm{C}$ ) all at long-day photoperiod $22 \mathrm{~L}: 2 \mathrm{D}$ were used, except for $M$. scabrinodis from Chupa where the temperature of $16^{\circ} \mathrm{C}$ was not used. From 3 to 7 (usually 5-6) cultures from each population were used in each experimental temperature.

Queens began to lay eggs soon after the start of the experiment. The workers reared these into rapid brood pupae and diapause larvae. Twice a week cultures were examined and all prepupae and pupae produced during the preceding week were removed and counted (they were not returned to nests). The presence of eggs and early instars larvae was also checked. When pupation stopped, eggs and early instars larvae disappeared, all the remaining third instar diapause larvae were counted in each culture. During these manipulations with ants they were anaesthetised by a short (up to 30 seconds) exposure to carbon-dioxide which is known to has no negative effect on brood rearing (Wardlaw, 1995). Worker mortality was not excessive (on average $<20 \%$ ) and not enough to affect broodrearing significantly.

From data obtained the following parameters were calculated for each group: the period of rapid brood pupation (the interval between the appearance of the first and the last pupa), the number of rapid brood pupae reared, the number of diapause larvae reared, the total number of brood produced (rapid plus diapause brood). The time of development (D) from egg to prepupa was also calculated for each culture by determining the period elapsed between the appearance of the first eggs and the first prepupae for which purpose their presence in ant cultures were checked each 1-2 days. The rate of development at a given temperature $(T)$ were calculated for each culture as $R_{T}=1 / D$.

The relationship between development rate and temperature in insects and many other poikilotherms is curvilinear at extreme temperatures, but at moderate temperature it is approximately linear, which feature allows to calculate so-called lower developmental threshold, or else thermal threshold for development (TTD) - the theoretical minimum temperature at which development will proceed assuming a linear relationship between development rate and temperature and the sum of effective temperatures (SET), or else the thermal requirement for development, i.e. the number of day-degrees above thermal threshold needed to complete development (Campbell et al., 1974; Ratte, 1985). The TTD and SET are widely used as important life-history traits, especially in comparative studies, usually to examine and illustrate the adaptations of insect populations to local environmental conditions (Campbell et al., 1974; Lamb et al., 1987; Tauber et al., 1987, 1988; Honěk \& Kocourek, 1990; Honěk, 1996a, b). This is why we also used linear regression analysis in our study.

Assuming a linear relationship between development rate and temperature in a restricted temperature range $\left(16-24^{\circ} \mathrm{C}\right)$ two coefficients of linear equation were estimated using regression analysis:

$$
\mathbf{R}_{\mathrm{T}}=\mathrm{a}+\mathrm{b} \times \mathrm{T}
$$

where $a$-intercept, $b$ - slope (i.e. the coefficient of linear regression of development rate on temperature). The value of TTD was estimated by extrapolating the regression line to $\mathrm{R}_{\mathrm{T}}=$ 0 , thus TTD $=-\mathrm{a} / \mathrm{b}$. SET was calculated as the reciprocal value of the slope: SET $=1 / \mathrm{b}$. The standard errors (SE) of intercept 


\section{Myrmica rubra}

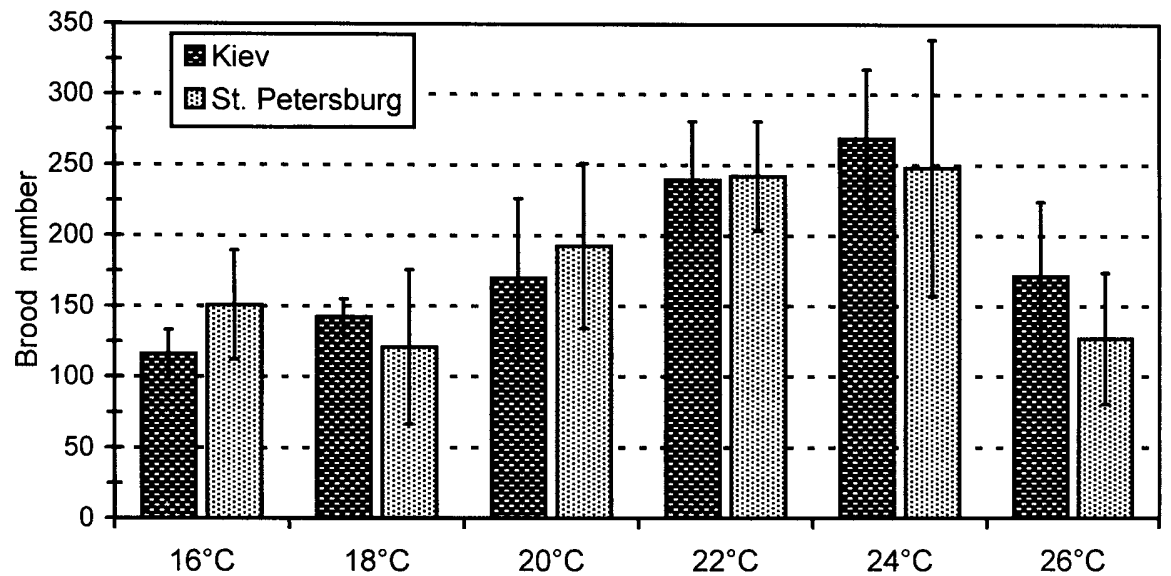

\section{Myrmica ruginodis}

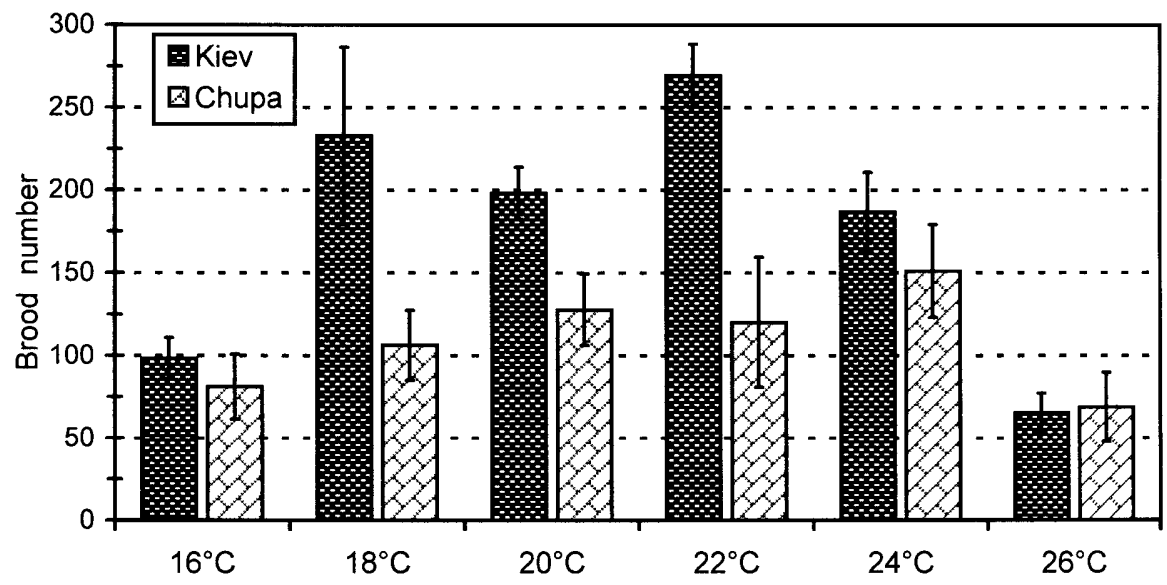

Myrmica scabrinodis

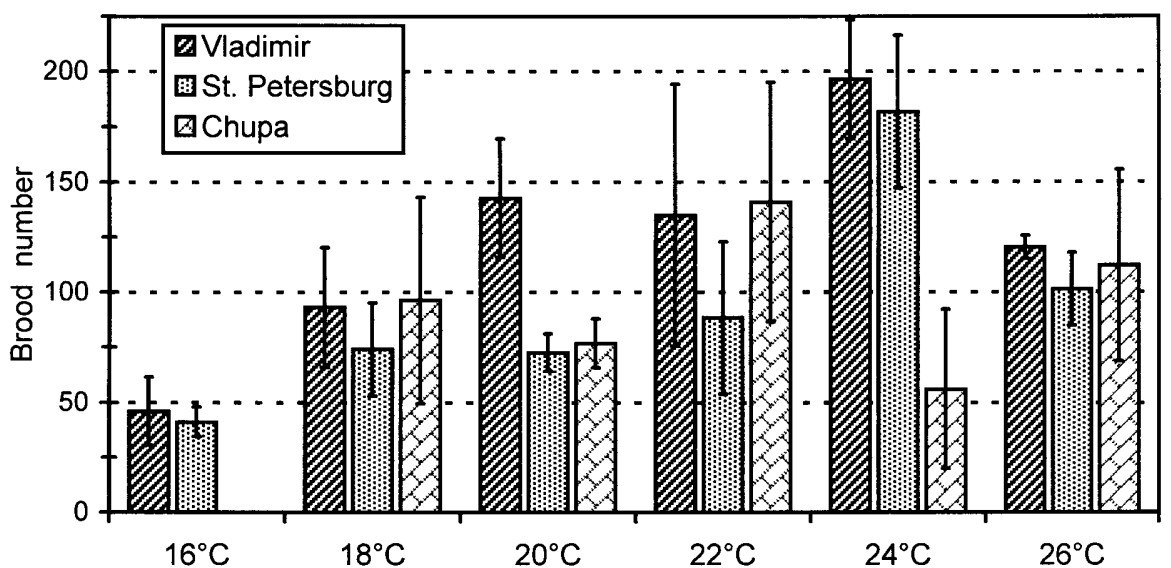

Fig. 1. Mean total brood production at six constant temperatures by experimental cultures of three Myrmica species from different geographic regions. Vertical bars - standard errors of means.

and slope were obtained from regression analysis, the SE values for TTD and SET were calculated using formulas given by Campbell et al. (1974).

Data were analysed by ANOVA using Statistica 4.1 package. Development times were more or less normally distributed and there were no significant correlations between means and variances. The reverse was true for other data which were very overdispersed in many experimental variants. Consequently we used data log transformation which apparently improved nor- mality and eliminated correlation between means and variances in most such cases. Tukey HSD test was used for post hoc comparison of means.

\section{RESULTS}

\section{Brood production}

The total production of brood (rapid brood pupae plus diapause larvae) by ant cultures (Fig. 1) was evidently 


\section{Myrmica rubra}

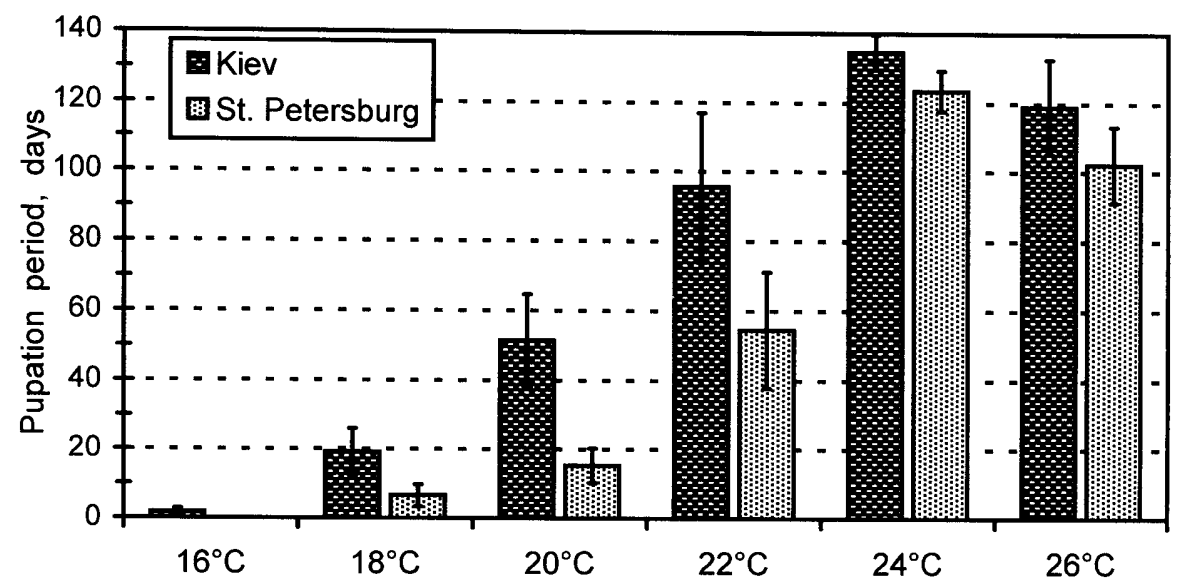

Myrmica ruginodis

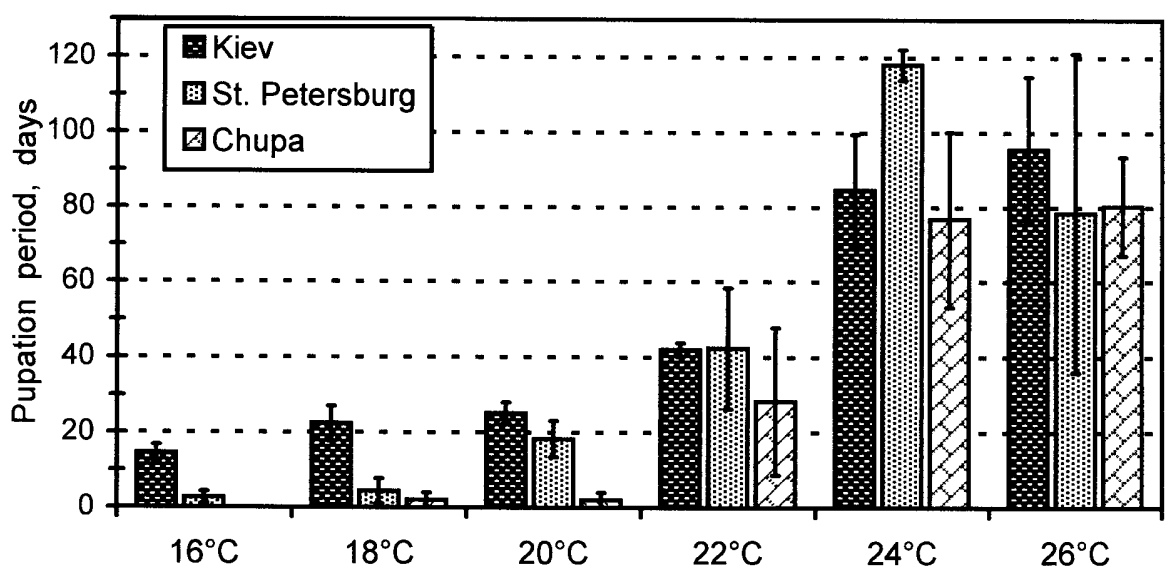

Myrmica scabrinodis

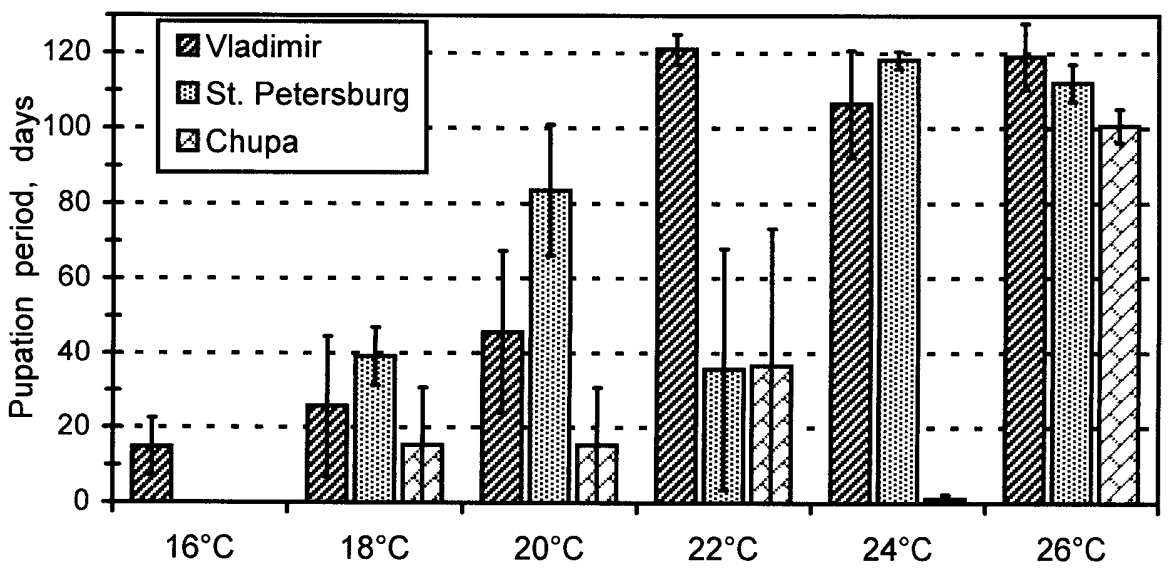

Fig. 2. Mean period of rapid brood pupation at six constant temperatures in experimental cultures of three Myrmica species from different geographic regions. Vertical bars - standard errors of means.

affected by temperature which influence appeared significant for all three species $\left(M\right.$. rubra $-\mathrm{F}_{5,58}=2.8, p<$ $0.024 ;$ M. ruginodis $-\mathrm{F}_{5,59}=8.6, p<0.001 ; M$. scabrinodis $-\mathrm{F}_{5,56}=3.3, p<0.012$ ). The highest brood production was observed at $22-24^{\circ} \mathrm{C}$ depending on species and population; the temperature of $26^{\circ} \mathrm{C}$ apparently suppressed brood rearing (Fig. 1). Two populations of $M$. rubra did not differ significantly in mean number of brood reared. In the case of St. Petersburg population of $M$. ruginodis the diapause larvae were not counted for technical reasons. But $M$. ruginodis cultures from Kiev produced significantly more brood at all temperatures except $26^{\circ} \mathrm{C}$ in comparison with those from Chupa $\left(\mathrm{F}_{1,59}=\right.$ $21.1, p<0.001)$. The differences in total brood production between $M$. scabrinodis populations did not appear significant mainly due to greater variation of this 
parameter (Fig. 1). A significant effect of site $\mathrm{x}$ temperature interaction $\left(\mathrm{F}_{5,59}=3.0, p<0.017\right)$ was found only for M. ruginodis.

The mean period during which rapid brood larvae pupated in ant cultures (Fig. 2) was significantly influenced by temperature in all three species $\left(M\right.$. rubra $-\mathrm{F}_{5,52}$ $=40.0, p<0.001 ; M$. ruginodis $-\mathrm{F}_{5,78}=42.8, p<0.001$; M. scabrinodis $-\mathrm{F}_{4,40}=10.0, p<0.001$ ). M. rubra cultures from St. Petersburg produced pupae during shorter time than cultures from Kiev at all temperatures $\left(\mathrm{F}_{1,52}=\right.$ $8.9, p<0.005$ ), these differences being much more marked at lower temperatures of $16-22^{\circ} \mathrm{C}$. The influence of site on the mean period of rapid brood pupation in $M$. ruginodis cultures was significant both by ANOVA $\left(\mathrm{F}_{2,78}\right.$ $=32.9, p<0.036)$ and by Tukey HSD test $(p<0.002)$. Again the differences between sites were greater at lower temperature range $\left(16-20^{\circ} \mathrm{C}\right) . M$. scabrinodis cultures from Vladimir and St. Petersburg appeared rather similar in the mean duration of pupation period but both differed significantly $(p<0.002)$ from Chupa cultures which produced pupae during shorter period. Only one out of three M. scabrinodis cultures from Chupa kept at $24^{\circ} \mathrm{C}$ reared 2 pupae, others did not produced pupae at all. This was obviously due to greater variation of rapid brood production observed among $M$. scabrinodis colonies (and also individual queens) some of which did not rear rapid brood even in optimal conditions. Cultures from 3 such colonies were placed at $24^{\circ} \mathrm{C}$ regime simply by chance which explained the unusually low value of pupation period obtained at $24^{\circ} \mathrm{C}$ (Fig. 2). A significant effect of site $\mathrm{x}$ temperature interaction $\left(\mathrm{F}_{8,40}=3.2, p<0.007\right)$ was found only for $M$. scabrinodis.

The differences between populations in temperature effects on the production of rapid brood pupae appeared even more pronounced and instructive (Fig. 3). The total production of pupae by ant cultures was clearly and significantly influenced by temperature in all species $(M$. rubra $-\mathrm{F}_{5,52}=21.0, p<0.0001 ;$ M. ruginodis $-\mathrm{F}_{5,78}=$ $46.0, p<0.0001 ;$ M. scabrinodis $\left.-\mathrm{F}_{4,40}=8.5, p<0.001\right)$. The maximum pupae production was observed at $24^{\circ} \mathrm{C}$ except $M$. ruginodis from $\mathrm{Kiev}$ which probably had a maximum at $22-23^{\circ} \mathrm{C}$ and $M$. scabrinodis from Chupa which did not produce rapid brood at $24^{\circ} \mathrm{C}$ by chance (see above). The temperature of $26^{\circ} \mathrm{C}$ apparently suppressed rapid brood production in $M$. rubra and $M$. ruginodis (Fig. 3). The influence of site on pupae production appeared significant in all species $\left(M\right.$. rubra $-\mathrm{F}_{1,52}=$ $10.2, p<0.003 ; M$. ruginodis $-\mathrm{F}_{2,78}=50.1, p<0.0001$; M. scabrinodis $-\mathrm{F}_{2,40}=11.5, p<0.0002$ ). The effects of site x temperature interaction appeared significant for $M$. ruginodis $\left(\mathrm{F}_{10,78}=2.7, p<0.007\right)$ and $M$. scabrinodis $\left(\mathrm{F}_{8,40}=2.7, p<0.018\right)$. All populations within each species differed quite significantly in pupae production, except between $M$. scabrinodis from Vladimir and St. Petersburg (Tukey HSD test: $p<0.002$ for $M$. rubra; $p<$ 0.007 for $M$. ruginodis; $p<0.005$ for $M$. scabrinodis $)$. Almost invariably more northern populations produced less rapid brood pupae in comparison with southern populations of the same species. These differences were much more pronounced at lower temperatures of $16-22^{\circ} \mathrm{C}$ (Fig. 3).

The effects of temperature on number of diapause larvae reared by ant cultures (Fig. 4) were significant both in $M$. rubra $\left(\mathrm{F}_{5,52}=3.5, p<0.009\right)$ and $M$. ruginodis $\left(\mathrm{F}_{5,59}\right.$ $=10.9, p<0.0001)$. The influence of site appeared, however, significant only in $M$. ruginodis $\left(\mathrm{F}_{1,59}=8.3, p<\right.$ $0.006)$ : the cultures of this species from Kiev reared more diapause larvae in comparison with those from Chupa. The interaction between site and temperature was insignificant in this case. The effects of both temperature and site on the production of diapause larvae in $M$. scabrinodis seemed uncertain (Fig. 4) and were found to be insignificant.

\section{Rate of development}

The increase of temperature invariably shortened the time of development from egg to prepupa in all species and populations (Fig. 5). The temperature of $26^{\circ} \mathrm{C}$ that has been shown above to be unfavourable for brood rearing clearly slowed down the development. This temperature was, therefore, excluded from further analysis. The influence of temperature from 16 to $24^{\circ} \mathrm{C}$ on the development time was highly significant in all species and populations ( $M$. rubra $-\mathrm{F}_{4,55}=20.8, p<0.0001 ; M$. ruginodis $-\mathrm{F}_{3,53}=54.6, p<0.0001 ; M$. scabrinodis $-\mathrm{F}_{4,50}$ $=100.5, p<0.0001$ ).

Whereas the influence of temperature on the development time is rather trivial, the effects of site deserve much more attention. These effects appeared significant in all species ( $M$. rubra $-\mathrm{F}_{1,55}=9.6, p<0.003 ;$ M. ruginodis $\mathrm{F}_{2,53}=8.3, p<0.0008 ;$ M. scabrinodis $-\mathrm{F}_{2,50}=4.3, p<$ 0.019). Almost invariably the development times of brood from more northern populations were a bit shorter in comparison with values obtained for southern populations of the same species, these differences being usually greater at higher temperatures $20-24^{\circ} \mathrm{C}$ (Fig. 5). Thus, eggs and larvae from more northern sites developed faster than southern brood. These differences appeared quite significant (Tukey HSD test) for $M$. rubra $(p<0.001)$ and $M$. ruginodis ( $p=0.0004-0.023$ ), except between St. Petersburg and Chupa populations which did not differ significantly. In $M$. scabrinodis the differences between populations were not so definite and only St. Petersburg and Chupa populations differed significantly $(p=0.034)$. No significant effects of interaction between site and temperature were found by ANOVA.

Parameters of linear regression of development rate on temperature, the values of the thermal threshold for development and of the sum of effective temperatures calculated for species and populations studied are given in Table 1, and the resulted regression lines are depicted in Fig. 6. The values of slope and SET differed significantly ( $t$-test: $p<0.05$ ) only between two populations of $M$. rubra. The coefficients of linear regression equation appeared very similar for St. Petersburg and Chupa populations of $M$. ruginodis and for Vladimir and St. Petersburg populations of $M$. scabrinodis. Nevertheless, the overall trend observed seems to be quite apparent: The slope of the regression line of development rate on tem- 


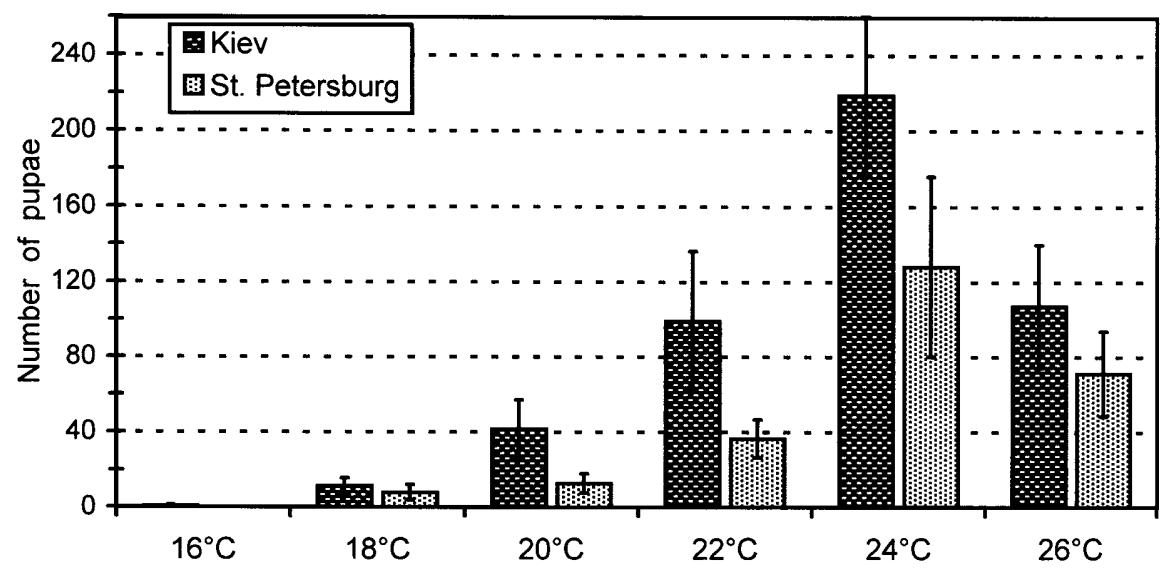

Myrmica ruginodis

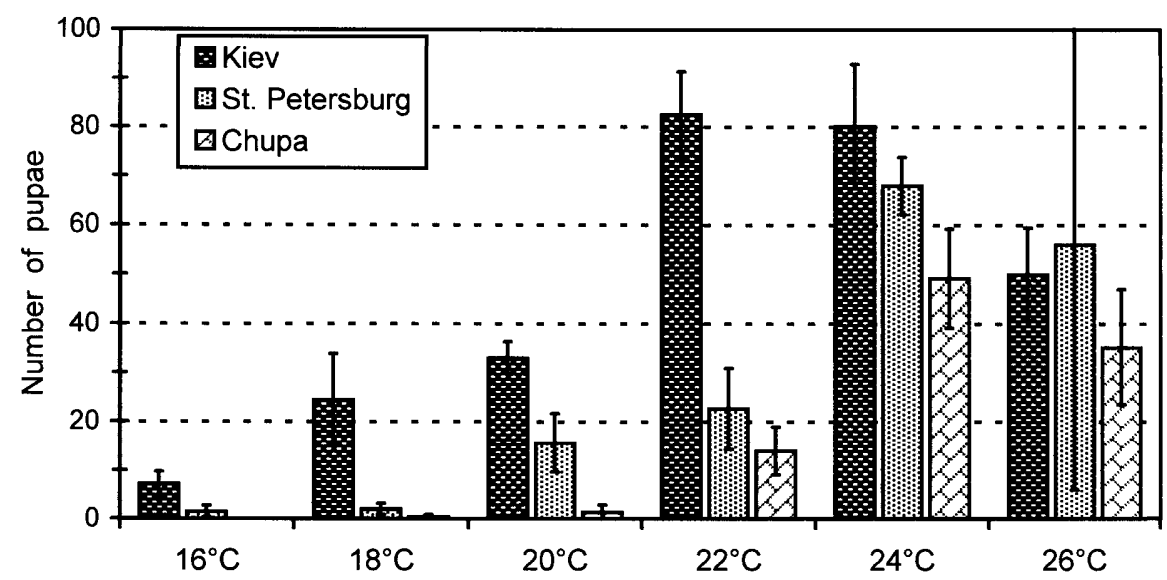

Myrmica scabrinodis

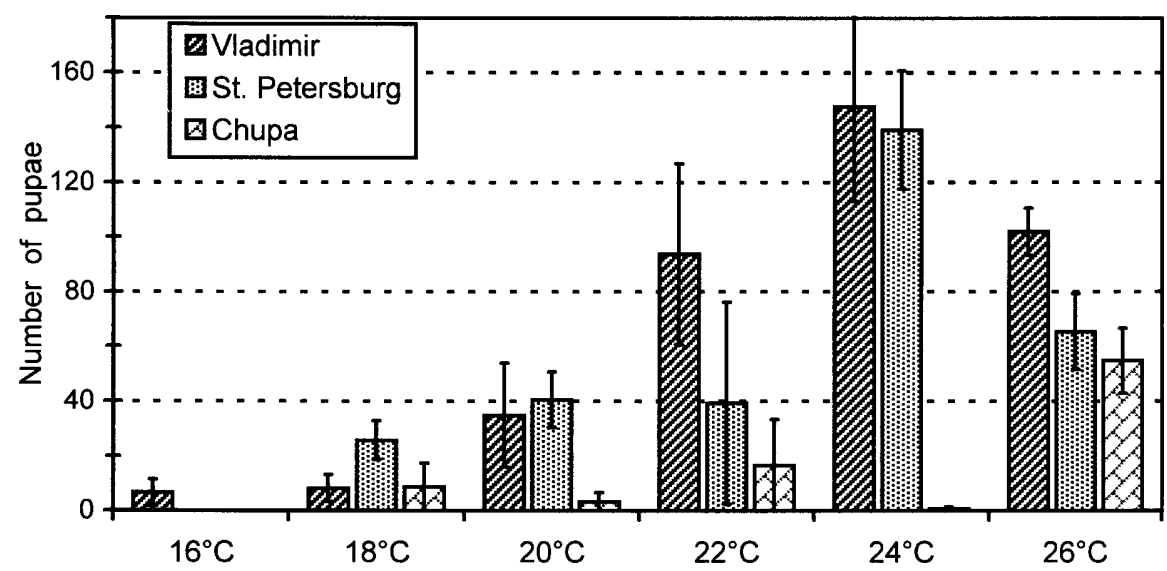

Fig. 3. Mean total production of rapid brood pupae at six constant temperatures by experimental cultures of three Myrmica species from different geographic regions. Vertical bars - standard errors of means.

perature and the value of thermal threshold increased in more northern populations. It is also worth to note that the sum of effective temperatures which is the reciprocal value of the slope decreased with the advance to the North. All this means that rapid brood development was more temperature dependent in northern Myrmica populations, the rates of development being a bit greater within higher temperature range (above $16-18^{\circ} \mathrm{C}$ ) but lesser at lower temperatures.

\section{Species comparison}

Apparent differences between species in the mean period of rapid brood pupation and the numbers of pupae reared were found (Figs 2-3). The overall influence of species appeared significant for pupation period $\left(\mathrm{F}_{2,66}=\right.$ 


\section{Myrmica rubra}

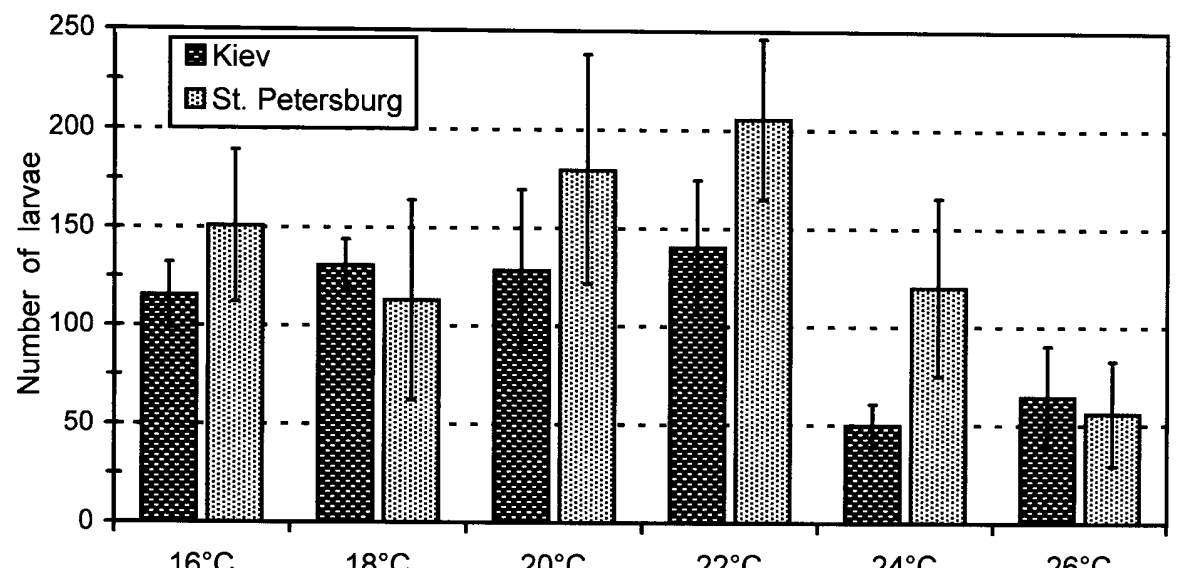

Myrmica ruginodis

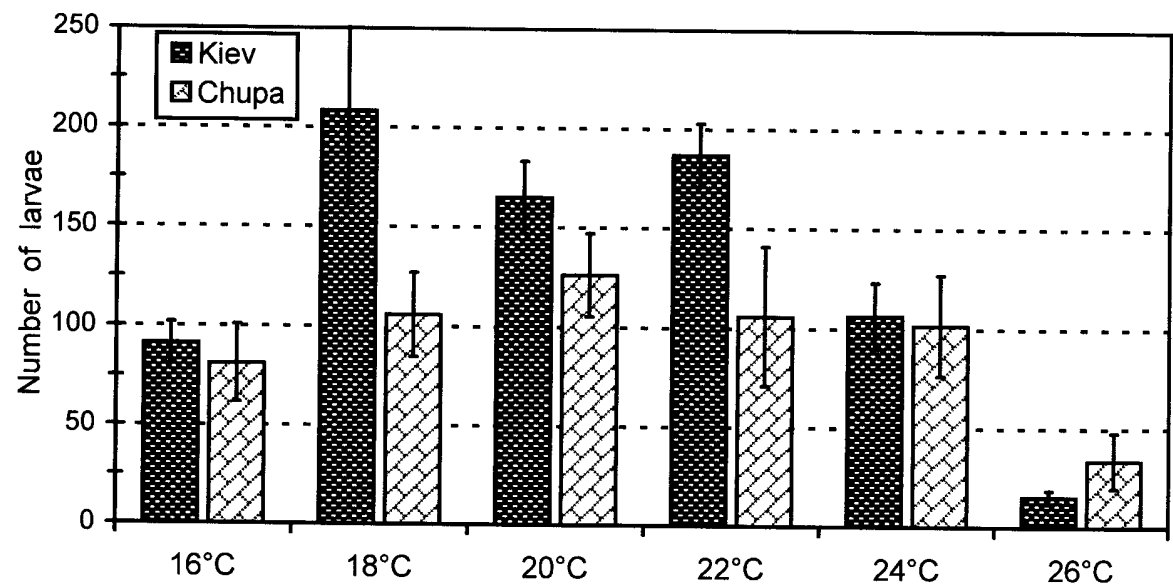

Myrmica scabrinodis

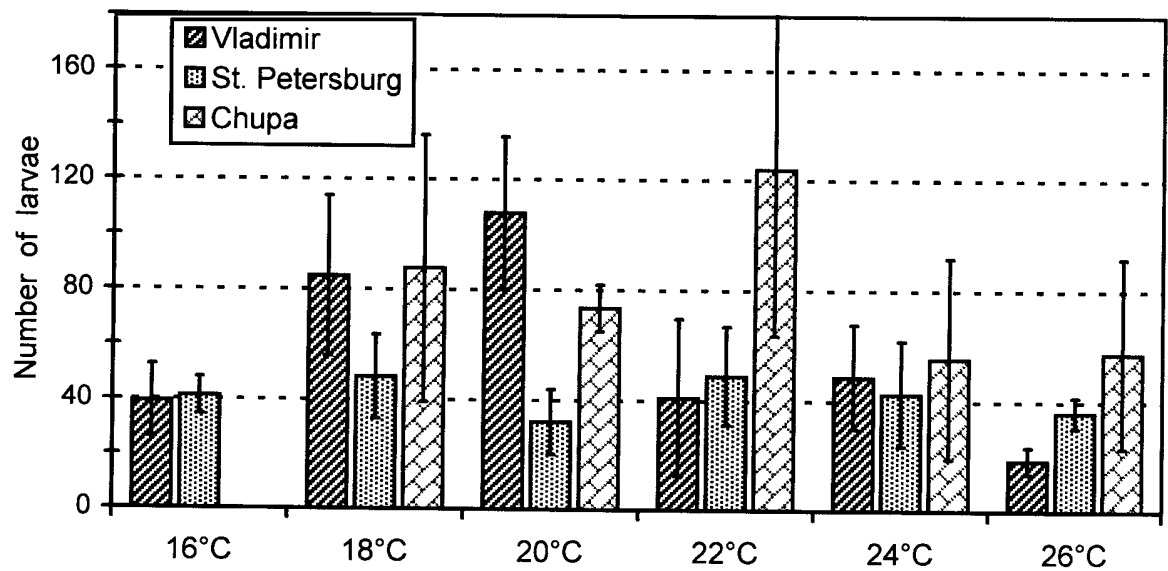

Fig. 4. Mean total production of diapause larvae at six constant temperatures by experimental cultures of three Myrmica species from different geographic regions. Vertical bars - standard errors of means.

$3.9, p<0.03$; for interaction species $\mathrm{x}$ temperature $\mathrm{F}_{10,66}=$ $2.0, p<0.042)$ but not for number of pupae. The period of pupation was usually longer and more pupae were produced in $M$. rubra as compared to $M$. ruginodis. The effect of species on these variables was significant (for periods: $\mathrm{F}_{1,100}=9.5, p<0.0027$; for numbers: $\mathrm{F}_{1,100}=$ 13.6, $p<0.0004)$, the species differences, however, appeared significant at post hoc comparison only between sympatric populations in Kiev $(p<0.001)$. A significant interaction effect was found only between species and temperature and only for pupae number $\left(\mathrm{F}_{5,100}=6.2, p<\right.$ $0.00005)$. M. ruginodis and $M$. scabrinodis differed significantly in the periods of pupation only in St. Petersburg $(p<0.0194)$ but not in Chupa. Nevertheless, the mean numbers of pupae produced by $M$. scabrinodis cultures were usually greater than in $M$. ruginodis from sympatric 


\section{Myrmica rubra}

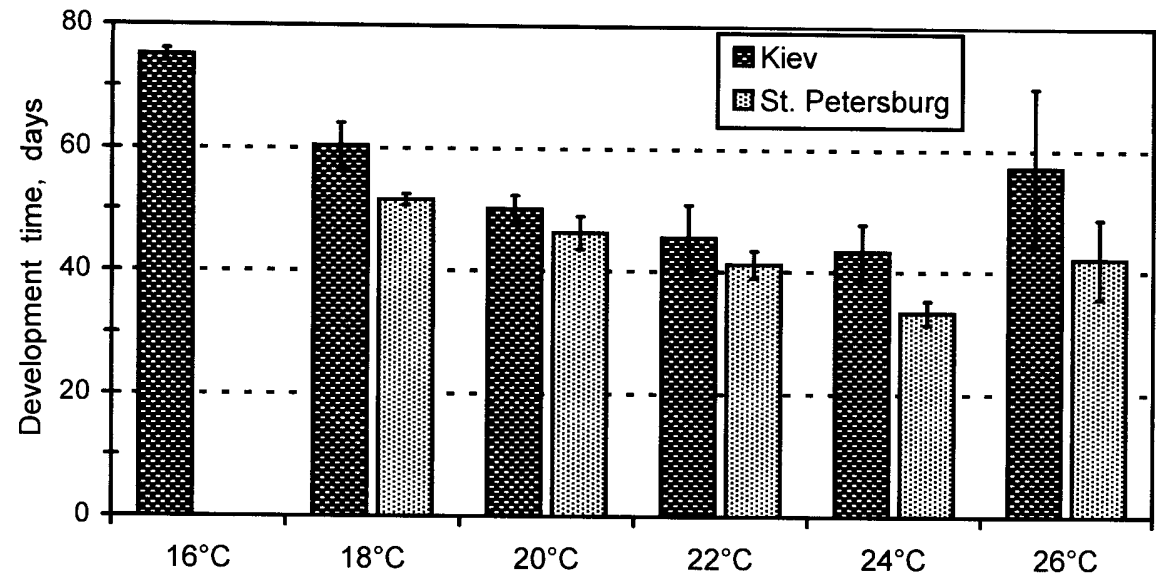

Myrmica ruginodis

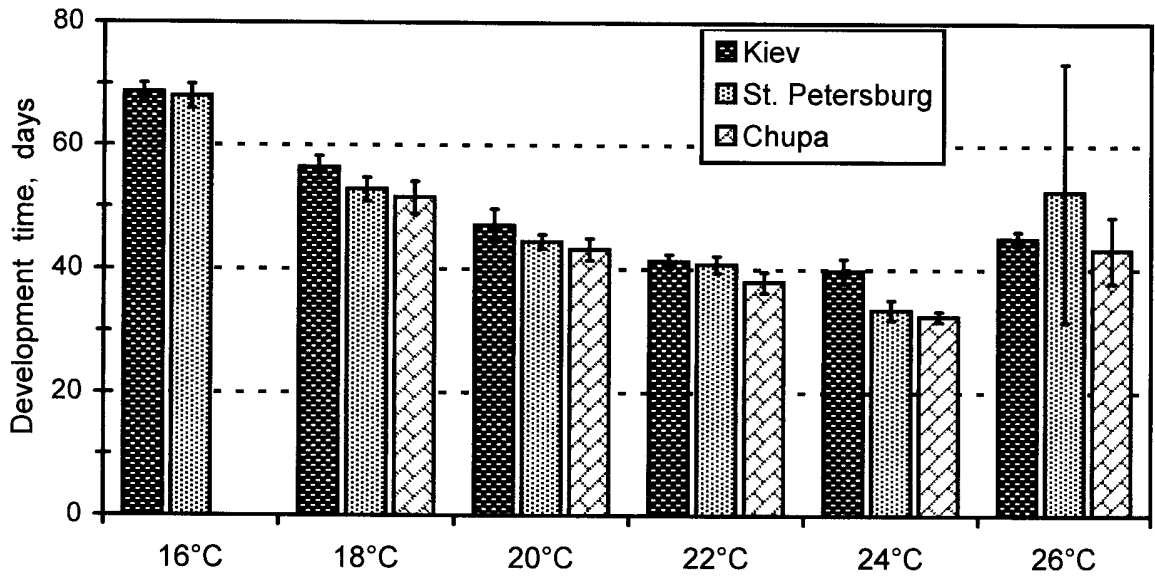

Myrmica scabrinodis

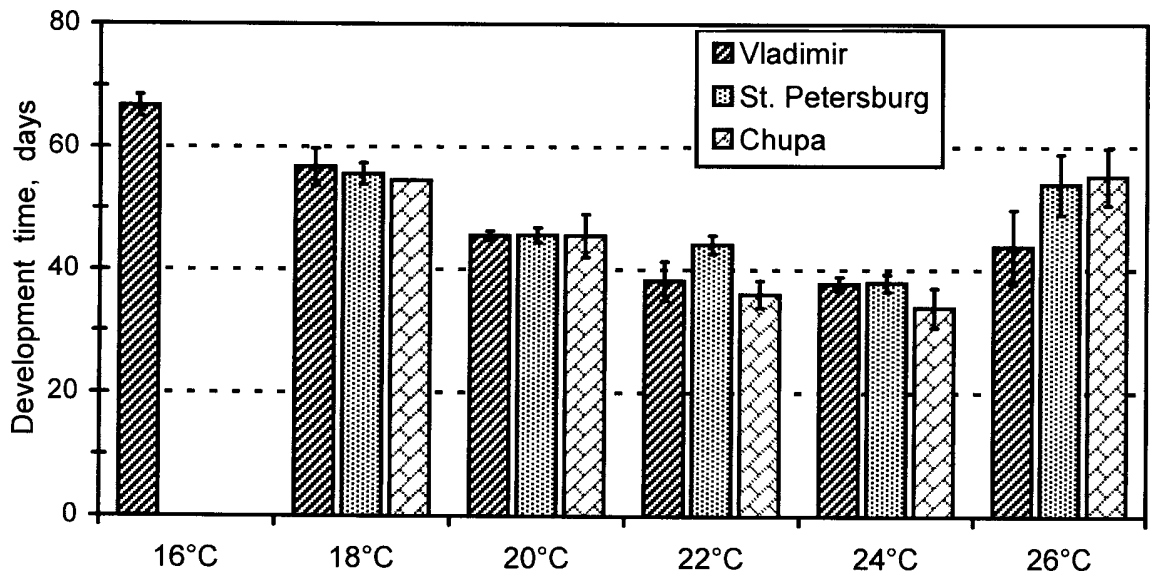

Fig. 5. Mean times of development from egg to prepupa at six constant temperatures in experimental cultures of three $M y r m i c a$ species from different geographic regions. Vertical bars - standard errors of means.

populations (Fig. 2); these differences were significant both by ANOVA $\left(\mathrm{F}_{1,64}=6.2, p<0.0154\right)$ and Tukey HSD test $(p<0.0129)$. There were significant effects of interactions species $\mathrm{x}$ site $\left(\mathrm{F}_{1,64}=9.7, p<0.0027\right)$ and site $\mathrm{x}$ temperature $\left(\mathrm{F}_{4,64}=5.9, p<0.0004\right)$. The cultures of $M$. scabrinodis from St. Petersburg reared on average just the same number of pupae as $M$. rubra cultures from sym- patric population at higher temperatures $\left(24-26^{\circ} \mathrm{C}\right)$ but significantly more pupae at lower temperature range $\left(16-22^{\circ} \mathrm{C}\right)$.

The effect of species on the development time from egg to prepupa appeared significant $\left(\mathrm{F}_{2,85}=5.6, p<0.0126\right)$ in St. Petersburg region, with no significant interaction species x temperature. Sympatric $M$. rubra and $M$. ruginodis 


\section{Myrmica rubra}

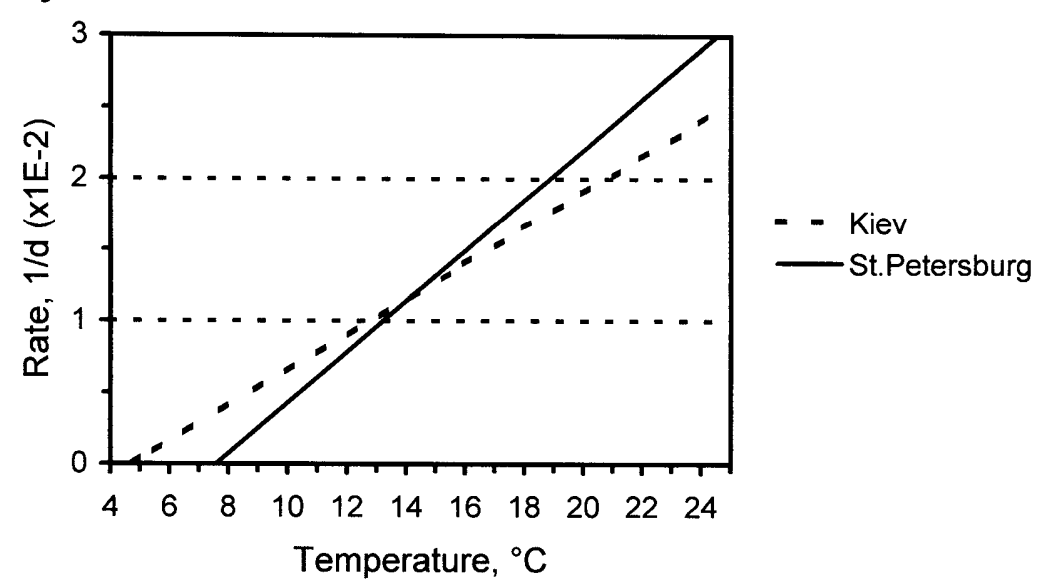

Myrmica ruginodis

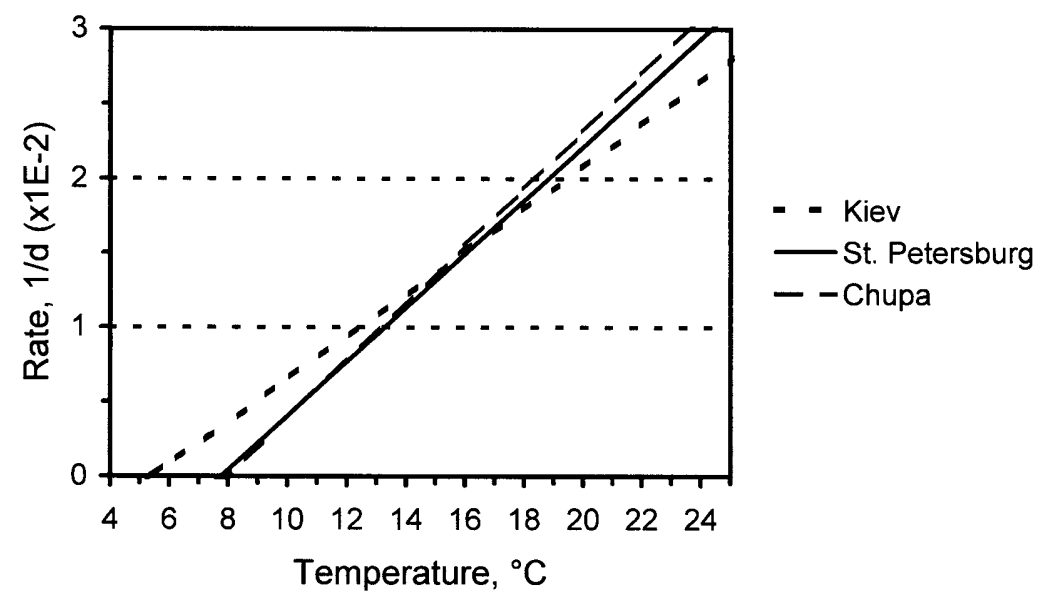

Myrmica scabrinodis

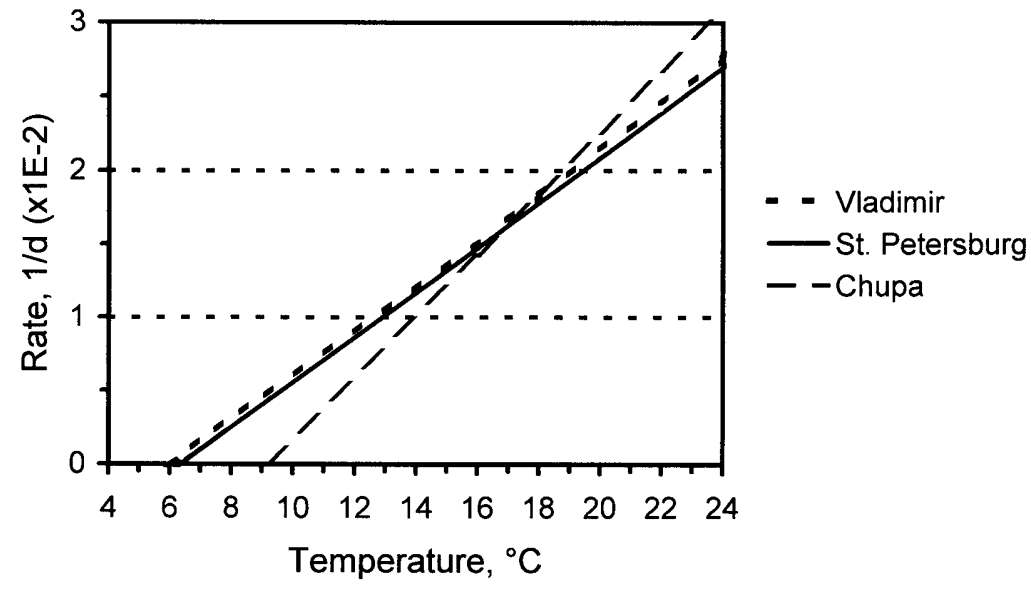

Fig. 6. The lines of linear regression of development rate on temperature for three Myrmica species from different geographic regions.

populations did not, however, differ significantly at post hoc comparison. These two species were evidently very similar both in Kiev and St. Petersburg regions in their development times (Fig. 5) and thermal requirements for development (similar values of slopes, intercepts, TTD and SET), although $M$. ruginodis seems to have a bit higher TTD and a bit lower SET in Kiev (Table 1, Fig. 6).
On the contrary, $M$. scabrinodis differed significantly both from M. rubra (in St. Petersburg; Tukey HSD: $p<$ 0.0092 ) and from $M$. ruginodis (in St. Petersburg and Chupa; ANOVA: $\mathrm{F}_{1,67}=4.7, p<0.0333$; Tukey HSD: $p<$ 0.0256 ; no significant effects of interactions species $\mathrm{x}$ site, species $\mathrm{x}$ temperature and site $\mathrm{x}$ temperature were found). However, whereas the development of M. scabri- 
TABLE 1. Thermal recquirements for rapid brood development from egg to prepupa in species and populations studied.

\begin{tabular}{|c|c|c|c|c|c|c|c|c|c|c|c|}
\hline \multirow[t]{2}{*}{ Species } & \multirow[t]{2}{*}{ Place } & \multirow[t]{2}{*}{$\begin{array}{l}\text { Number of } \\
\text { tempera- } \\
\text { tures used }\end{array}$} & \multirow[t]{2}{*}{$\begin{array}{l}\text { Number } \\
\text { of obser- } \\
\text { vations }\end{array}$} & \multicolumn{4}{|c|}{$\begin{array}{l}\text { Parameters of linear regression of } \\
\text { development rate on temperature } \\
\qquad\left(\times 10^{-2}\right)\end{array}$} & \multirow[t]{2}{*}{$\begin{array}{l}\text { TTD } \\
\left({ }^{\circ} \mathrm{C}\right)\end{array}$} & \multirow[t]{2}{*}{$\begin{array}{l}\text { SE of } \\
\text { TTD } \\
\left({ }^{\circ} \mathrm{C}\right)\end{array}$} & \multirow[t]{2}{*}{$\begin{array}{l}\text { SET } \\
\text { (dd) }\end{array}$} & \multirow[t]{2}{*}{$\begin{array}{l}\text { SE } \\
\text { of SET } \\
\text { (dd) }\end{array}$} \\
\hline & & & & Intercept & $\begin{array}{c}\text { SE of } \\
\text { intercept }\end{array}$ & Slope & $\begin{array}{l}\text { SE of } \\
\text { slope }\end{array}$ & & & & \\
\hline Myrmica rubra & $\begin{array}{l}\text { Kiev } \\
\text { St. Petersburg }\end{array}$ & $\begin{array}{l}5 \\
5\end{array}$ & $\begin{array}{l}22 \\
43\end{array}$ & $\begin{array}{l}-0.60^{\mathrm{A}} \\
-1.34^{\mathrm{A}}\end{array}$ & $\begin{array}{l}0.090 \\
0.105\end{array}$ & $\begin{array}{l}0.13^{\mathrm{A}} \\
0.18^{\mathrm{A}}\end{array}$ & $\begin{array}{l}0.014 \\
0.024\end{array}$ & $\begin{array}{l}4.8 \\
7.8\end{array}$ & $\begin{array}{l}2.26 \\
1.76\end{array}$ & $\begin{array}{l}802^{\mathrm{A}} \\
547^{\mathrm{A}}\end{array}$ & $\begin{array}{l}91.5 \\
72.6\end{array}$ \\
\hline Myrmica ruginodis & $\begin{array}{l}\text { Kiev } \\
\text { St. Petersburg } \\
\text { Chupa }\end{array}$ & $\begin{array}{l}5 \\
5 \\
4\end{array}$ & $\begin{array}{l}30 \\
22 \\
22\end{array}$ & $\begin{array}{l}-0.77^{\mathrm{BC}} \\
-1.40^{\mathrm{B}} \\
-1.52^{\mathrm{C}}\end{array}$ & $\begin{array}{l}0.210 \\
0.228 \\
0.246\end{array}$ & $\begin{array}{l}0.14 \\
0.18 \\
0.19\end{array}$ & $\begin{array}{l}0.013 \\
0.020 \\
0.025\end{array}$ & $\begin{array}{l}5.4 \\
7.8 \\
7.9\end{array}$ & $\begin{array}{l}1.36 \\
1.45 \\
1.85\end{array}$ & $\begin{array}{l}703 \\
553 \\
521\end{array}$ & $\begin{array}{l}64.8 \\
60.4 \\
68.1\end{array}$ \\
\hline Myrmica scabrinodis & $\begin{array}{l}\text { Vladimir } \\
\text { St. Petersburg } \\
\text { Chupa }\end{array}$ & $\begin{array}{l}5 \\
5 \\
5\end{array}$ & $\begin{array}{l}18 \\
35 \\
12\end{array}$ & $\begin{array}{l}-0.95^{\mathrm{D}} \\
-0.97^{\mathrm{E}} \\
-1.91^{\mathrm{DE}}\end{array}$ & $\begin{array}{l}0.219 \\
0.239 \\
0.300\end{array}$ & $\begin{array}{l}0.15 \\
0.15 \\
0.21\end{array}$ & $\begin{array}{l}0.019 \\
0.015 \\
0.030\end{array}$ & $\begin{array}{l}6.1 \\
6.4 \\
9.2\end{array}$ & $\begin{array}{l}1.74 \\
1.44 \\
1.67\end{array}$ & $\begin{array}{c}648 \\
655 \\
480\end{array}$ & $\begin{array}{l}77.6 \\
65.6 \\
70.2\end{array}$ \\
\hline
\end{tabular}

TTD - Thermal threshold for development $\left({ }^{\circ} \mathrm{C}\right)$; SET (dd) - sum of effective temperatures (day-degrees).

The values of intercept, slope and SET marked with the same letters differ significantly $(t$-test: $p<0.05)$ within the same species.

nodis brood was clearly less temperature dependent (lesser slopes and TTD and greater SET) compared to sympatric $M$. rubra and $M$. ruginodis in St. Petersburg, it appeared even more temperature dependent compared to sympatric $M$. ruginodis population in Chupa (Tab. 1, Fig. 6). The calculations showed that in St. Petersburg $M$. scabrinodis brood would need the temperature of $23.5^{\circ} \mathrm{C}$ to develop at the same rate as sympatric $M$. rubra or $M$. ruginodis brood at $22^{\circ} \mathrm{C}$, whereas in Chupa it would need only $21.7^{\circ} \mathrm{C}$. This difference in thermal requirement for development between $M$. scabrinodis and $M$. ruginodis was shown to be much greater $\left(2-3^{\circ} \mathrm{C}\right)$ in Southern England by Elmes \& Wardlaw (1983).

\section{CONCLUSIONS AND DISCUSSION}

This study shows the distinct latitudinal variation in the temperature effects on rapid brood rearing and in the thermal requirements for brood development in three Myrmica species.

First, the period during which new rapid brood pupae appear in ant cultures is found to be longer and the total number of pupae produced to be greater in ants from more southern populations in most experimental variants. The number of diapause larvae reared by ant cultures was also usually greater in ants from southern sites. These results are in good agreement with our previous studies which have revealed the same latitudinal differences in the length of colony's intrinsic seasonal cycle of rapid brood rearing and in the number of pupae produced with the use of $M$. rubra and $M$. ruginodis populations from two geographical region - Belgorod and St. Petersburg (Kipyatkov \& Lopatina, 1997).

Much more interesting is, however, the finding that low temperatures reduce the period of rapid brood production and the number of pupae reared to a greater degree in ants from northern populations. The differences in these two parameters observed between experimental cultures kept at relatively low $\left(16-18^{\circ} \mathrm{C}\right)$ and relatively high $\left(20-24^{\circ} \mathrm{C}\right)$ temperatures always appeared much more pronounced in ants from northern sites. It means that northern Myrmica colonies rear rapid brood under lower temperatures evi- dently worse in comparison with ants from southern regions.

Besides that eggs and larvae from more northern sites appear to develop faster than southern brood at temperatures above $16-18^{\circ} \mathrm{C}$. This is because brood development in northern populations is more temperature dependent, i.e. is characterised by higher slopes of regression lines of development rate on temperature. In other words the sum of effective temperatures (thermal requirement for development), which is the reciprocal value of the slope, decreases with the advance to the North. It is also worth to note that the higher slopes of regression lines are always associated with higher thermal thresholds for development (Fig. 6). Although the causes of such a correlation are still open to question (e.g. Groeters, 1992; Trudgill \& Perry, 1994; Trudgill, 1995) its existence has been recently confirmed by the thorough analysis of published data both at interspecific (i.e. between species) and intraspecific (i.e. between populations of a species) levels (Honěk \& Kocourek, 1990; Honěk, 1996a,b).

We conclude from this that the reaction norm of $\mathrm{Myr}$ mica colonies, in response to temperature, changes according to the local climate in such a way that brood rearing, growth and development of individuals become more temperature dependent in more severe environments with colder and shorter summers. This lead to the increase of the physiological and developmental responses at higher temperatures at the expense of a decrease within lower temperature range. These adaptive changes in the reaction norm to temperature are best illustrated by the differences in the slopes of regression lines of the development rates on temperatures found between Myrmica populations living at different latitudes (Fig. 6). Earlier, the similar change in the reaction norm to temperature was demonstrated in respiration studies using the same three Myrmica species: populations from higher latitudes had higher Q10s, i.e. their metabolism was more intensive than that of southern populations at higher temperatures but less intensive at lower temperatures (Elmes et al., 1999; Nielsen et al., 1999). Thus, the respiratory metabolism in individual ants from northern populations also appears more dependent on temperature. Such 
changes of the reaction norms to temperature allow northern Myrmica colonies "to live faster" and to respond more quickly to occasionally favourable temperatures.

In fact Myrmica colonies from northern populations need on average higher temperatures in their nests for successful production of new adults as compared to southern ants. Our unpublished data on nest microclimate confirm this conclusion suggesting that northern Myrmica colonies really rear their brood even at higher average temperatures than southern ants owing to the adaptive changes in habitat preferences and the improvements of the thermal characteristics of the nests.

It is rather surprising that ants, contrary to a lot of other arthropods, adapt to boreal environments by increasing their thermophily, i.e. by relying upon higher temperatures for more rapid development and productive brood rearing. This unusual trait is undoubtedly related to the fact that originally thermophilic ants manage to exist in boreal regions only owing to special construction of their nests destined to collect sunshine and to rise the temperature inside (Brian, 1983). All these phenomena are evidently worth further study.

ACKNOWLEDGEMENTS. We are very much grateful to Dr. Alexander Radchenko and Dr. Vadim Fomenko for their invaluable help in collecting ant colonies in Kiev and Vladimir. We are also much obliged to two anonymous reviewers for their important advice and comments on the manuscript. This work was supported by Russian Foundation of Basic Research (grant No 00-04-49003), as well as by The Council for Grants from the President of Russian Federation and for State Support of Leading Scientific Schools (grant No 00-15-97934).

\section{REFERENCES}

BrIAN M.V. 1951: Summer population changes in colonies of the ant Myrmica. Physiol. Comp. Oecol. 2: 248-262.

BrIAN M.V. 1955: Studies of caste differentiation in Myrmica rubra L. Larval dormancy, winter size and vernalisation. Insectes Soc. 2: 85-114.

BrIAN M.V. 1957: Serial organization of brood in Myrmica. Insectes Soc. 4: 191-210.

BrIAN M.V. 1983: Social Insects: Ecology and Behavioural Biology. Chapman \& Hall, London and New York, $\mathrm{x}+377$ pp.

Campbell A., Fraser B.D., Gilbert N., Gutierrez A.P. \& MACKAUER M. 1974: Temperature requirements of some aphids and their parasites. J. Appl. Ecol. 11: 431-438.

Danks H.V. 1981: Arctic Arthropods. A Review of Systematics and Ecology with Particular Reference to the North American Fanna. Entomological Society of Canada, Ottawa, vii +608 pp.

Downes J.A. 1965: Adaptations of insects in the arctic. Annu. Rev. Entomol. 10: 257-274.

Elmes G.W. 1991: The social biology of Myrmica ants. Actes Colloq. Insectes Soc. 7: 17-34.

Elmes G.W. \& Thomas J.A. 1987: Die Biologie und Ökologie der Ameisen Gattung Myrmica. In: Geiger W. (ed.): Tagfalter und ihre Lebensraume: Arten, Gefahrdung, Schutz. Schweizerischer Bund für Naturschutz, Basle, pp. 404-409.

Elmes G.W. \& WardLAW J.C. 1983: A comparison of the effect of temperature on the development of large hibernated larvae of four species of Myrmica (Hym.: Formicidae). Insectes Soc. 30: $106-118$.
Elmes G.W., Wardlaw J.C., Nielsen M.G., Kipyatkov V.E., Lopatina E.B., Radchenko A.G. \& Barr B. 1999: Site latitude influences on respiration rate, fat content and the ability of worker ants to rear larvae: A comparison of Myrmica rubra (Hymenoptera: Formicidae) populations over their European range. Eur. J. Entomol. 96: 117-124.

GroETERS F.R. 1992: Geographic conservatism of development rate in the milkweed-oleander aphid, Aphis nerii. Acta Oecol. 13: 649-661.

Heinze J. \& Hölldobler B. 1994: Ants in the cold. Memorabilia Zool. 48: 99-108.

Holgersen H. 1942: Ants of Northern Norway (Hym.: Form.). Vol. 63, Tromsø Mus. Åarsh. Naturhistorisk. Avd. K. Karlsens Trykkeri, Tromsø, 33 pp.

HoNĚK A. 1996a: Geographical variation in thermal requirements for insect development. Eur. J. Entomol. 93: 303-312.

HoNĚK A. 1996b: The relationship between thermal constants for insect development: a verification. Acta Soc. Zool. Bohem. 60: $115-152$.

HoNEKK A. \& KoCOUREK F. 1990: Temperature and development time in insects: a general relationship between thermal constants. Zool. Jb. Syst. 117: 401-439.

KIPYATKOV V.E. 1974: Studies of photoperiodic reaction in the ant Myrmica rubra L. (Hymenoptera: Formicidae). I. Main parameters of the reaction. Entomol. Obozr. 53: 535-545. [in Russian with English summary]

KrpYatKov V.E. 1977: Studies of photoperiodic reaction in the ant Myrmica rubra (Hymenoptera: Formicidae). III. Peculiarities of temperature correction. Vestn. Leningrad Univ. 3: 14-21. [in Russian with English summary]

KipYATKOV V.E. 1993: Annual cycles of development in ants: diversity, evolution, regulation. In: Kipyatkov V.E. (ed.): Proceedings of the Colloquia on Social Insects. Vol. 2, Russian-speaking Section of the IUSSI, Socium, St. Petersburg, pp. 25-48.

KrPYATKOV V.E. 1995: Role of endogenous rhythms in the regulation of annual cycles of development in ants (Hymenoptera: Formicidae). Entomol. Rev. 74: 1-15.

KipYAtKov V.E. 2001: Seasonal life cycles and the forms of dormancy in ants (Hymenoptera: Formicoidea). Acta Soc. Zool. Bohem. 65: 211-238.

Kipyatkov V.E. \& Lopatina E.B. 1997: Experimental study of seasonal cycle of rapid brood production in the ants Myrmica rubra L. and M. ruginodis Nyl. from two different latitudes. In: Kipyatkov V.E. (ed.): Proceedings of the International Colloquia on Social Insects. Vol. 3-4, Russian Language Section of the IUSSI, Socium, St. Petersburg, pp. 195-206.

KusNezov N. 1957: Numbers of species of ants in faunae of different latitudes. Evolution 11: 298-299.

Lamb R.J., MacKay P.A. \& Gerber G.H. 1987: Are development and growth of pea aphids, Acyrthosiphon pisum, in North America adapted to local temperatures? Oecologia 72: $170-177$.

Lopatina E.B., Kipyatkov V.E., Imamgaliev A.A. \& Dubovaya L.A. 1999: South-North differences in the impact of temperature on the seasonal cycle of oviposition and development in three species of Myrmica ants. Abstracts of the 5th International Colloquium on Social Insects, Moscow 4-8 October 1999, Russian Language Section of the IUSSI, p. 46.

Nielsen M.G. 1987: The ant fauna (Hymenoptera: Formicidae) in northern and interior Alaska. A survey along the transAlaskan pipeline and a few highways. Entomol. News 98: 74-88.

Nielsen M.G., Elmes G.W. \& Kipyatkov V.E. 1999: Respiratory Q10 varies between populations of two species of Myr- 
mica ants according to the latitude of their sites. J. Insect Physiol. 45: 559-564.

Ratte H.T. 1985: Temperature and insect development. In: Hoffmann K.H. (ed.): Environmental Physiology and Biochemistry of Insects. Springer Verlag, Berlin, Heidelberg, New York, Tokyo, pp. 33-66.

Tauber C.A., Tauber M.J., Gollands B., Wright R.J. \& OBRYCKi J.J. 1988: Preimaginal development and reproductive responses to temperature in two populations of the Colorado potato beetle (Coleoptera: Chrysomelidae). Ann. Entomol. Soc. Am. 81: 755-763.
Tauber C.A., Tauber M.J. \& Nechols J.R. 1987: Thermal requirements for development in Chrysopa oculata: a georgaphically stable trait. Ecology 68: 1479-1487.

TRUdGill D.L. 1995: Why do tropical poikilothermic organisms tend to have higher threshold temperature for development than temperate ones? Funct. Ecol. 9: 136-137.

Trudgill D.L. \& Perry J.N. 1994: Thermal time and ecological strategies - a unifying hypothesis. Ann. Appl. Biol. 125: $521-532$.

WARDLAW J.C. 1995: The effect of carbon dioxide on egg production in Myrmica rubra. Insectes Soc. 42: 325-328.

Received December 12, 2001; revised April 17, 2002; accepted April 18, 2002 